\title{
EMERGENCE DYNAMICS OF DIAMESA CHEIMATOPHILA HANSEN (DIPTERA: CHIRONOMIDAE: DIAMESINAE)
}

\section{LEONARD C. FERRINGTON JR ${ }^{1, *}$ and EDWIN MASTELLER ${ }^{2}$}

\author{
${ }^{1}$ Department of Entomology, University of Minnesota, Saint Paul, MN 55126, USA \\ 2 Professor of Biology Emeritus, The Pennsylvania State University, Behrend College, 4701 College Drive, Erie, PA 16563, USA \\ *Corresponding Author: ferri016@umn.edu
}

\begin{abstract}
Emergence of Diamesa cheimatophila was determined for a five year period (1981-1986) using a permanently operated walk-in emergence trap over a spring-fed tributary of Fourmile Creek in Erie, northeast Pennsylvania. Annual emergence started in September/October, continued sporadically through winter until April/May and occurred over a span of 185-236 days. Averaged over the five years of our study, $>80 \%$ of annual emergence occurred during winter when long-term average air temperatures are less than 10 degrees $\mathrm{C}$. Emergence of $D$. cheimatophila shows patterns similar to emergence of $D$. mendotae Muttkowski at groundwater-influenced stream sites in Minnesota, where it is known to produce 2-3 cohorts per year during winter. Well-defined peaks in winter emergence of $D$. cheimatophila indicates at least two, but possibly three or four cohorts emerging per winter. The year-to-year variability in emergence of $D$. cheimatophila strongly suggests this species also conforms to the Labile Life Cycle Hypothesis proposed for D. mendotae, (but refined in this paper) with the actual number of cohorts produced per winter depending on the onset and duration of cold air temperatures.
\end{abstract}

Keywords: winter emergence, labile life cycle hypothesis, voltinism, phenology

\section{Introduction}

Chironomidae of the subfamily Diamesinae are generally considered to be among the most-cold adapted species (Rossaro 1991; Lencioni 2004), are often more predominant in streams and rivers of arctic or sub-arctic regions, or are commonly collected in upper reaches of glacial-melt streams and cold springs at lower latitudes (Rossaro et al 2000). In warmer climates species of the genus Diamesa have been shown to emerge sporadically during winter (Ferrington 2000; Bouchard and Ferrington 2009; Anderson and Ferrington 2012), but larvae are often not detected or are rare during warmer-water periods in the same streams (Ferrington, personal observations) and presumably diapause or migrate to hyporheic regions. Although these observations previously suggested a univoltine, fast-seasonal life cycle, Bouchard and Ferrington (2009) have shown that Diamesa mendotae Muttkowski can be bivoltine or possibly trivoltine in Minnesota. Consequently, Ferrington et al. (2010) developed two alternative models to account for winter emergence dynamics (a "leakage hypothesis" versus a "labile life cycle hypothesis") and Anderson et al. (2013) concluded that the labile life cycle hypothesis was most consistent with empirical data for Diamesa mendotae.

Diamesa cheimatophila Hansen, 1976 was described based on 29 males in twelve field collections located across central New York. Females and immature stages remain unknown, and little is known about the life cycle and emergence patterns. This species, however, was among the most numerous species encountered during winter in a long-term assessment of aquatic insects in a spring-fed tributary of Fourmile Creek in Erie, PA referred to locally as "Trout Run." Adults were collected in a walk-in emergence trap operated for multiple years. Based on these collections, we summarize the emergence patterns of this species and speculate on the potential of it to complete more than one generation per year during winter at this locality. We also argue that the emergence patterns of this species in this stream are consistent with a modified "labile life cycle hypothesis" model.

\section{Material and Methods}

The sample site is located within a densely forested track of land just north of the football stadium and sports fields along the north edge of the Behrend College campus of Penn State University in Erie Pennsylvania. The walk-in emergence trap was located on Trout Run, a tributary of Fourmile Creek (for more detailed site description see Adler et al. 1982). The site was located within a deeply incised segment of stream that is strongly shaded by mature deciduous trees, and stream bottom substrates consist of bed-rock, broken bedrock, boulders and gravels with small amounts of intervening sands. The stream flow is strongly groundwater-dominated and cool in summer, but remained ice-free in winters during the duration of this study.

The walk-in emergence trap covered a 2-meter by 2 -meter area of stream bottom and was constructed to extend from bank to bank during normal base flows, and was similar in design but smaller than an earlier version described by Masteller (1977, also see photograph in Masteller and Buzby 1993). Emerging adults were collected regularly from the inside of the trap using bat- 
tery operated or hand-held aspirators into small collection jars. Specimens were returned to a science lab on the Behrend College campus, placed into a freezer, then sorted to family and preserved with $80 \%$ ETOH. Samples were collected periodically, usually three-times per week and the emergence trap was in place continuously over the five-year span summarized in this publication. All samples for the period of July 1981-June 1986 were checked for adults of Diamesinae which were removed when encountered, counted and placed into four-dram vials for longer-term storage.

Selected specimens of adult males were removed, cleared and slide-mounted according to protocols described in Sæther (1969). Slide-mounted voucher specimens have been deposited in the insect collections of the Kansas Biological Survey (Lawrence, Kansas, USA) and in the personal collection of E. C. Masteller housed at the Tom Ridge Environmental Center, Presque Isle in Erie, PA. Some additional specimens still in ETOH are available from L. C. Ferrington Jr at the University of Minnesota.

Long-term average daily (=LTAD) air temperatures and actual average daily (AAD) air temperatures were obtained from the National Meteorological files for the nearest local station in Erie, PA. Departures of AAD air temperatures from LTAD air temperatures were calculated for each day on which adults were collected in the emergence trap. The total numbers of specimens emerging on particular dates were summed as a function of range of LTAD air temperatures for each year of the study. The numbers of individuals emerging per day were also related to ranges in departures of AAD air temperatures from LTAD air temperatures.

\section{Results}

Inter-annual emergence abundance from 1981-1986 is shown in Fig. 1. During this time period the earliest emergence of Diamesa cheimatophila was during September and in each year emergence was completed by the third week in May or earlier. No emergence occurred from June through the first two weeks of September. The number of adults collected annually in the emergence trap averaged 3,943 adults/year, but varied substantially from a high of 8,254 in 1982-83 to the low of 1,379 in 1985-86. The corresponding density values of adult emergence averaged 986/square meter over the 5-year period, with a high of 2064/square meter in 1982-83 and low of 375/square meter in 1985-86.

The duration between first emergence in fall to last emergence in spring varied from as short as 185 days (1982/83) to a long as 236 days (1981/82), and exceeded 215 days during the remaining years $(1985 / 86=217$ days; $1984 / 85=233$ days; $1983 / 84=236$ days). Averaged across all five winters, the mean duration for emergence was 221 days/year.

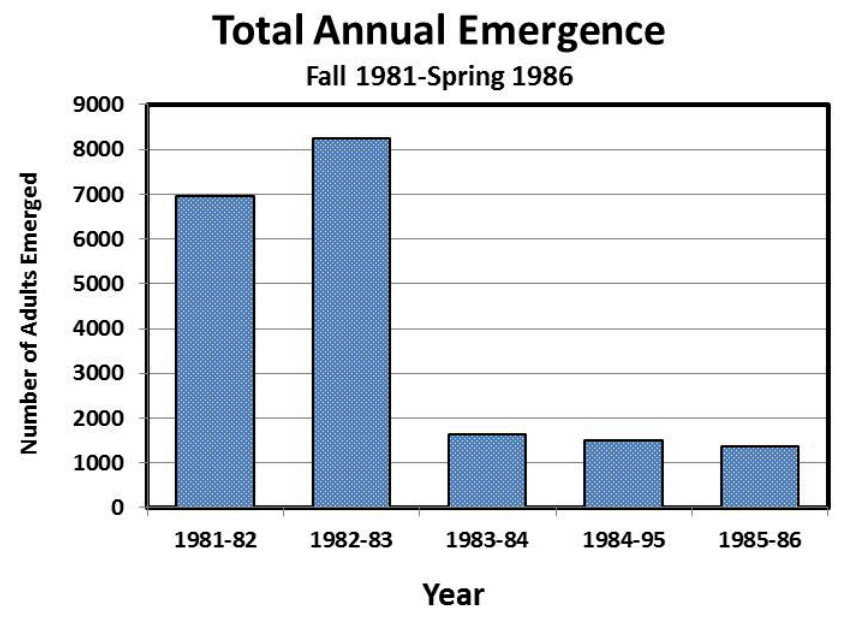

Fig. 1 Total annual emergence collected with tent trap.

All emergence occurred at LTAD air temperatures ranging from $-5.0^{\circ} \mathrm{C}$ to $+15.6{ }^{\circ} \mathrm{C}$ (Figs. $2 \mathrm{a}-\mathrm{e}$ ) and $\mathrm{AAD}$ air temperatures of $-12.2^{\circ} \mathrm{C}$ to $+21.7^{\circ} \mathrm{C}$. The number and corresponding percent of annual emergence as a function of ranges of LTAD air temperatures varied considerably across the 5 -years, but more than $98 \%$ of annual emergence during each year occurred at LTAD air temperatures of $12{ }^{\circ} \mathrm{C}$ or less.

Weekly peaks in emergence were detectable during each of the five annual emergence periods (Figs. 3a-e). The timing and number of weekly peaks differs among the five years of the study, but two or more peaks are visible during each winter. Peaks are separated by periods with no emergences during winter 1981/82 and 1985/86. During other winters the peaks are interspersed by several two-week periods with very low emergence.

Fig. 4 shows cumulative emergence as a function of LATD and AAD calculated across all 5-years of this study. A small percentage of emergence occurred when AAD was less than $-5^{\circ} \mathrm{C}$ or greater than $+17^{\circ} \mathrm{C}$. Between these two extremes, more emergence occurred when AAD exceeded LATD. Calculated across all five years, $63.9 \%$ of adults emerged during periods with LATD air temperatures below freezing. However, only $29.2 \%$ of adults emerged at $\mathrm{AAD}$ air temperatures below freezing.

\section{Discussion}

Diamesa cheimatophila was the most abundant Diamesinae emerging during cooler months of the year in Trout Run. Other Diamesinae were very rare compared to $D$. cheimatophila, but included Diamesa nivoriunda (Fitch) (less than 50 specimens/year), and undetermined species of Pagastia and Potthastia (each less than 30 specimens/year). Based on abundance and emergence timing during coldest months of the year, the winter emergence of Diamesa cheimatophila closely resembles the patterns of Diamesa mendotae in groundwater dominated trout streams in Minnesota (Bouchard and Ferrington 2009; Anderson and Ferrington 2012). Both of these species 
a) Emergence Versus Mean Daily Air Temperature Fall 1981-Spring 1982

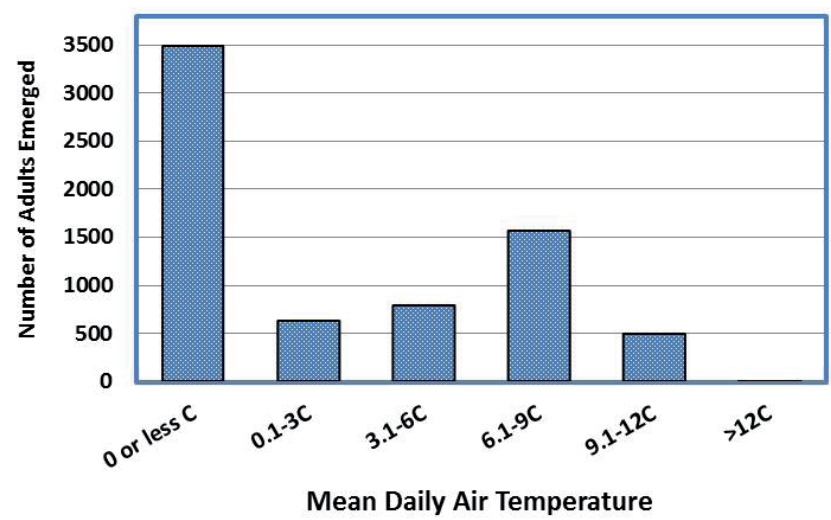

c) Emergence Versus Mean Daily Air Temperature Fall 1983-Spring 1984

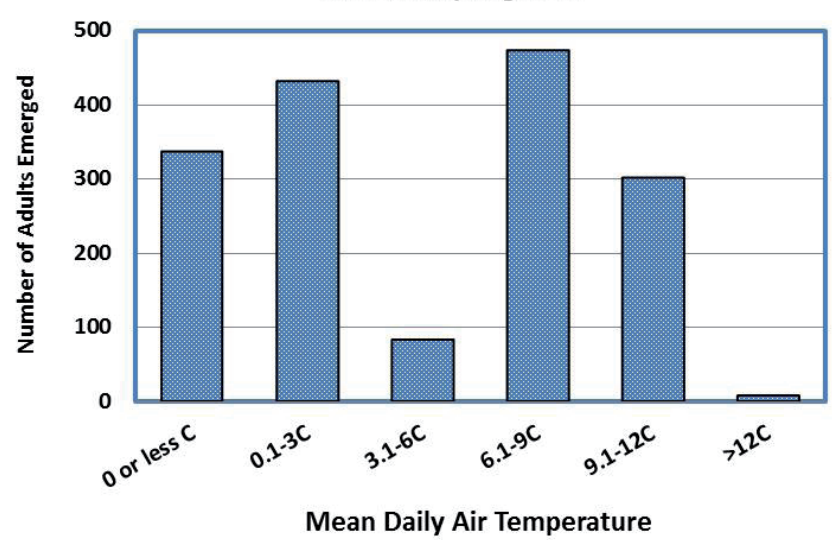

b) Emergence Versus Mean Daily Air Temperature Fall 1982-Spring 1983

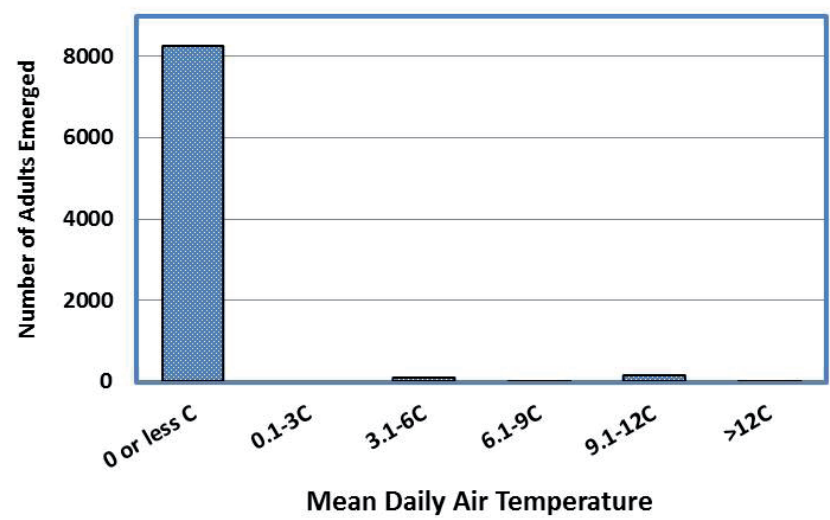

d) Emergence Versus Mean Daily Air Temperature Fall 1984-Spring 1985

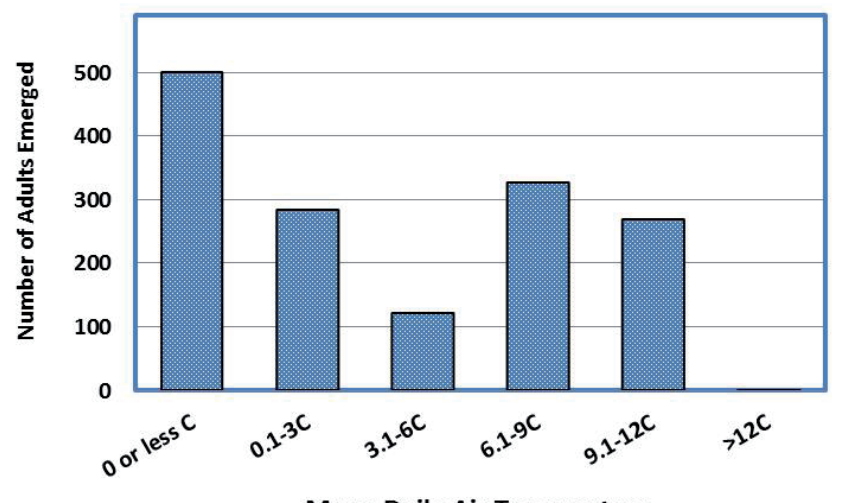

Mean Daily Air Temperature

e) Emergence Versus Mean Daily Air Temperature Fall 1985-Spring 1986

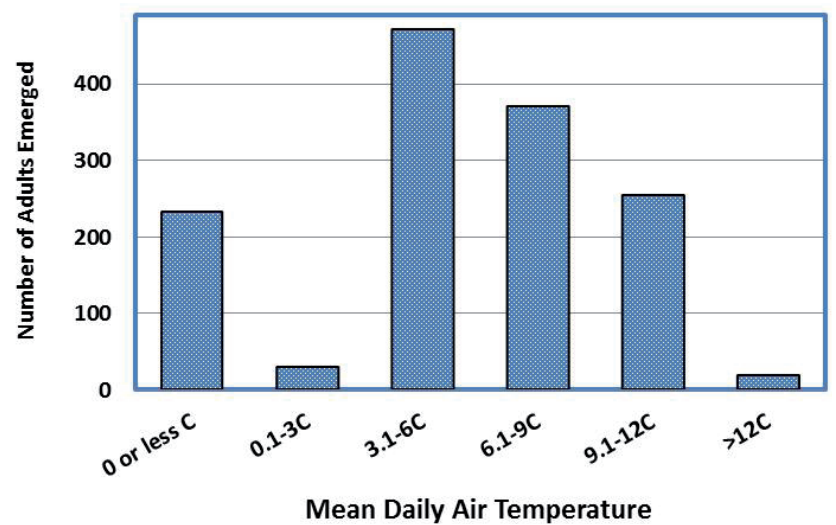

Fig. 2 Emergence in relation to mean daily air temperature (=LTAD) on date of collection. 


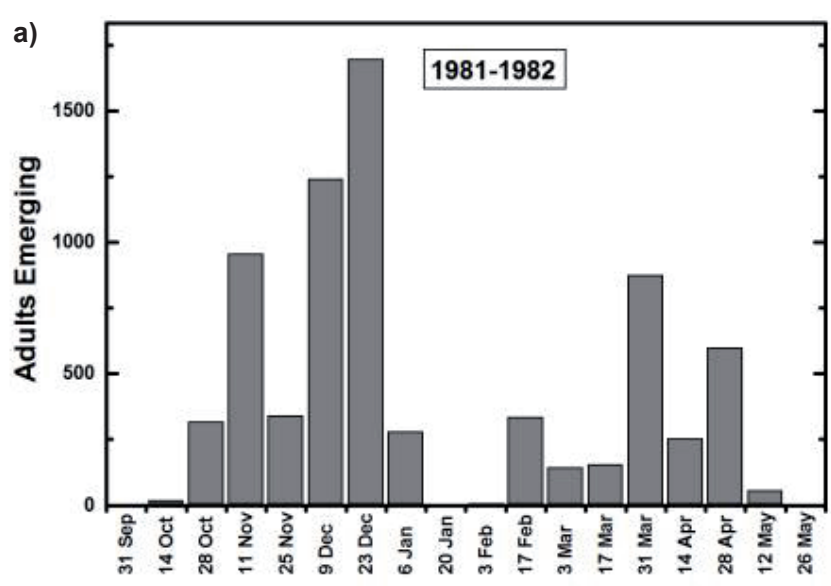

Emergence During Two-week Period Ending

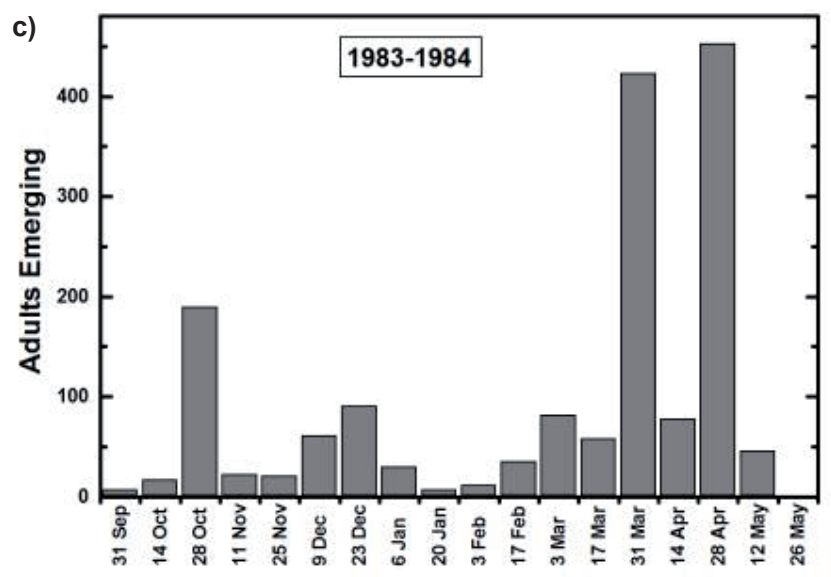

Emergence During Two-week Period Ending

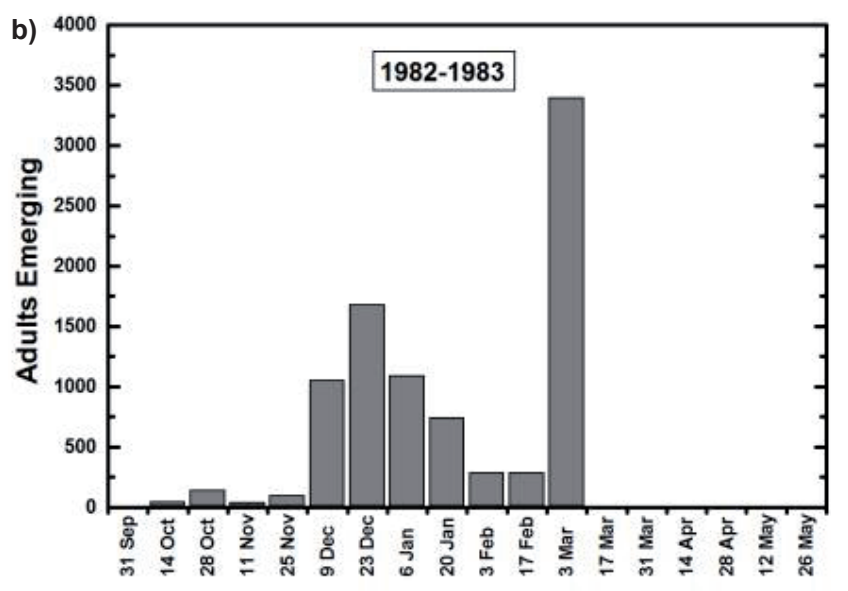

Emergence During Two-week Period Ending

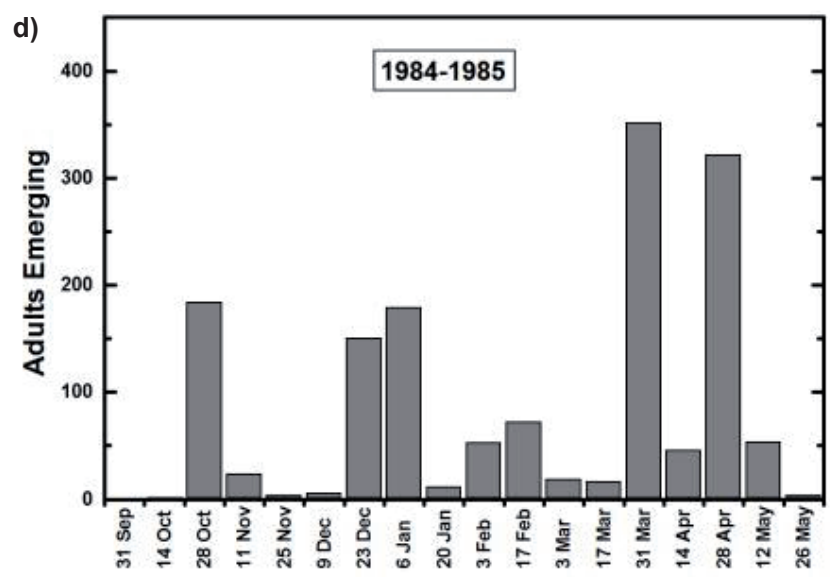

Emergence During Two-week Period Ending

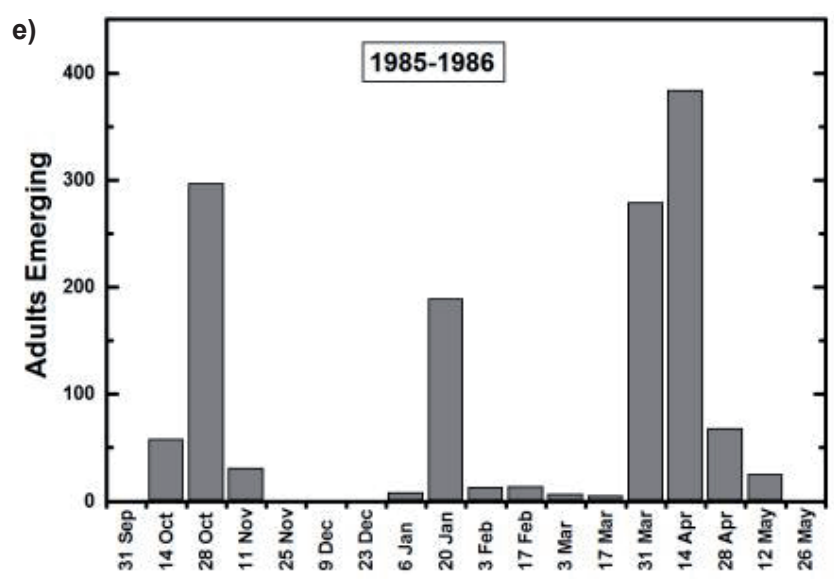

Emergence During Two-week Period Ending

Fig. 3 Emergence in relation to two-week periods between September and May. 


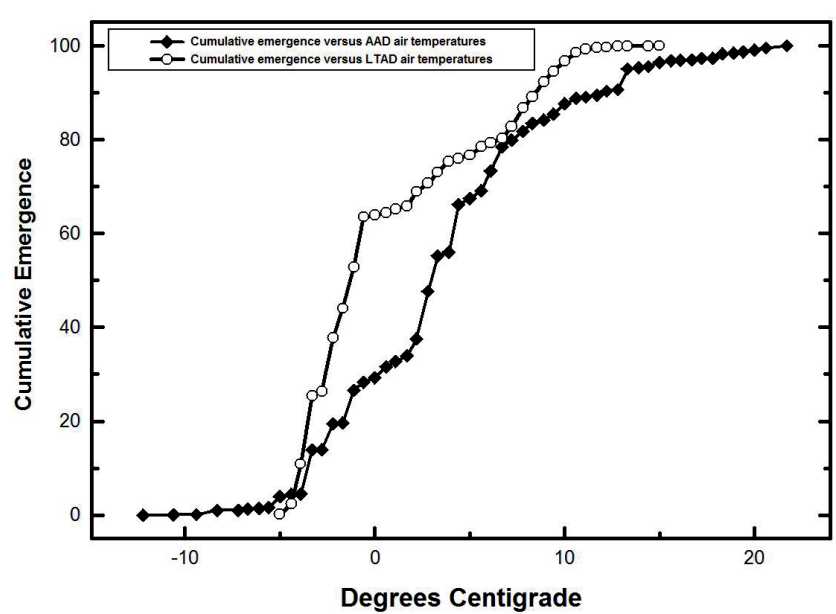

Fig. 4 Cumulative emergence (all five years) in relation to LTAD and $A A D$ air temperatures.

complete substantial amounts of annual emergence and are active as adults, often on snow, at air temperatures below freezing.

The annual average number of days between first emergence in fall to last emergence in spring (221 days/ year) compares favorably with the annual average duration of emergence of $D$. mendotae in Minnesota re-calculated from annual data reported by Bouchard and Ferrington (2009) (253 days/year). Field experiments in isolated chambers confirmed that more than one generation of $D$. mendotae can grow to maturity and emerge during cooler water temperatures less than $10^{\circ} \mathrm{C}$ and the extended annual period of winter emergence results from two or more successive generations. Based on the pattern for $D$. mendotae, it is likely that the extended annual emergence periods of $D$. cheimatophila also represent emergence of two or more successive generations during winter.

Winter emergence by Diamesa cheimatophila at this site on Trout Run is facilitated by groundwater input, both upstream and in the immediate vicinity of the sample site, which keeps water temperatures above freezing during even the coldest month of the year. During our study the stream did not totally freeze-over at the sample site, similar to streams in Minnesota where the life-cycle of Diamesa mendotae has been studied and shown to emerge over extended periods of cold ambient air conditions. Similarly, Diamesa incallida (Walker) has been shown to be active as adults and oviposit during winter near the spring sources of Breitenbach, a first order stream in central Germany, with annual mean water temperatures of $7.6^{\circ} \mathrm{C}$ and $7.8^{\circ} \mathrm{C}$. Both D. mendotae and $D$. incallida have been shown to produce more than one generation per year, including more than one generation during winter months at air and water temperatures similar to those that occur in Trout Run. Although voltinism cannot be confirmed with only emergence data, the results for these other two species of Diamesa, combined with the long duration of emergence, the prevalence of annual emergence occurring at mean air temperatures below $10{ }^{\circ} \mathrm{C}$, and the winter peaks in abundances documented in our study collectively suggests that $D$. cheimatophila is at least bivoltine in winter of some years, and possibly multivoltine during other winters.

Short generation times at water temperatures below $10{ }^{\circ} \mathrm{C}$ have been estimated for both $D$. incallida and D. mendotae. Estimates for generations developing in mid- or late-winter range from 39-43 days at water temperatures from $6.7^{\circ} \mathrm{C}$ to $9.2^{\circ} \mathrm{C}$ for $D$. incallida, to 63 days when water temperatures ranged between $4{ }^{\circ} \mathrm{C}$ to $6^{\circ} \mathrm{C}$ and 93 days with water temperatures mostly between $8{ }^{\circ} \mathrm{C}$ to $10^{\circ} \mathrm{C}$ for $D$. mendotae. Although the generation time of D. cheimatophila is unknown, it is possible to make some assumptions that guide interpretation of the peaks shown in Figs. 3a-e. Assuming a hypothetical average generation time of 70 days (plus or minus $20 \%$ ) and maximum development rate between $4{ }^{\circ} \mathrm{C}$ and $9{ }^{\circ} \mathrm{C}$, leads to the prediction that some individuals of a given cohort would emerge 56 days after oviposition and others as late as 84 days. This would also equate to an average 28-day emergence window for a generation. Consequently the first generation in fall starting emergence in September or early October would be predicted to complete emergence by about 25 November during all five winters of our study. This prediction compares favorably to the well-developed peaks in emergence for this putative first generation that are visible in 1981/82 for the two-week period ending 11 November and again in 1983/84, 1984/85 and $1985 / 86$ for the two-week period ending 28 October. No pronounced peak was observed in 1982/83 for the putative first generation in either October or November, but small numbers of individuals emerged during every two week period up through the two-week period ending in late November.

Based on the assumptions made earlier, a second generation could begin emerging by early December in Trout Run, and a third generation by late February. Comparing these predictions with actual results for the five years of this study suggests that the peaks of abundance in mid-December during 1981/82, 1982/83, 1983/84 would represent the most pronounced emergence of the second generation. Peaks ending on 6 January 1985 and 20 January 1986 would be the corresponding, but slightly delayed maximum emergence periods of the putative second generations in the winters of 1984/85 and 1985/86.

Applying the same hypothetical assumptions and logic to the remaining months during the annual periods of emergence leads to the conclusions that a third generation begins emerging in February in each year except 1985/1986 when the third generation would be delayed until March and with peak emergence occurring during the two week period ending 14 April. In both 1982/83 and 1985/86 there are no obvious peaks that would suggest a fourth generation.

By contrast to $1982 / 83$ and $1985 / 86$, the emergences in April and May during 1981/82, 1983/84 and 1984/85 
would be interpretable as fourth generation adults, with peaks during two-week periods ending 28 April in all three years.

Differences in the numbers of putative generations during winter in the five years of this study suggest there is plasticity in developmental rates that likely correspond to differing annual thermal regimes. Bouchard and Ferrington (2009) showed that developmental period of fourth instars of $D$. mendotae increased at higher water temperatures. Although maximum development rates of may occur in the range of $4-8{ }^{\circ} \mathrm{C}$, it is also likely that slower development rates occur lower temperatures. This suggests that year-to-year differences in thermal regimes may alter the voltinism of D. mendotae. Applying similar reasoning to the annual emergence patterns of $D$. cheimatophila potentially accounts for the putative numbers of generations, and it will be necessary to develop a more finely tuned model where average development rate can vary as a function of water temperature.

Krider et al. (2013) refined a regression model relating mean air temperatures to water temperatures for groundwater-dominated trout streams in Minnesota that enable water temperature conditions to be predicted. The model shows that sections of stream strongly dominated by groundwater inputs have longer potential to remain within the range of $4-8{ }^{\circ} \mathrm{C}$. The models are developed and calibrated for individual streams and provide output that can be used to predict voltinism of $D$. mendotae across a wide range of streams in southeastern Minnesota. A comprehensive regression model is not available for Trout Run. However a tentative, but unvalidated, model based on periodic single point measurements of water temperature for Trout Run, predicts that in years when air temperatures are cooler than average in early autumn and again in early spring, there will be more days when the stream water temperatures range between $4-8{ }^{\circ} \mathrm{C}$. Assuming that $D$. cheimatophila has developmental responses to water temperature that are similar to D. mendotae, it can be predicted that early decline in air temperatures in autumn and cooler air temperatures later into spring would result in maximum developmental rates through winter that increase voltinism of $D$. cheimatophila in Trout Run. By contrast, delays in the onset of cooler air temperatures in autumn, combined with early warming in the spring will decrease voltinism. A refined regression model for Trout Run, based on automated simultaneous recordings of air and water temperatures, would allow a test of this prediction.

In this paper we have presented emergence data with regard to both LTAD and AAD air temperatures which allows for alternative interpretations of how emergence is influenced by air temperature. LTAD provides a view of the way in which the species has adapted to emerging in the colder portions of the year, and demonstrates that $D$. cheimatophila has the potential to emerge during even the average coldest periods of the year, with more than $63 \%$ of emergence occurring when LTAD temperatures are expected to be less than $0{ }^{\circ} \mathrm{C}$. Emergence, however, seems to be influenced by actual air temperatures and with individuals slightly shifting their dates of emergence to times when actual air temperatures are above LTAD air temperatures. As shown by Fig. 4, the departures of adult emergence from $\mathrm{LTAD}$ to $\mathrm{AAD}$ are greatest between the range of $-2{ }^{\circ} \mathrm{C}$ and $+4{ }^{\circ} \mathrm{C}$ air temperature.

Ferrington et al. (2010) proposed a "labile life cycle hypothesis" model for winter emergence of $D$. mendotae in which periodic bursts of emergence during winter were viewed as a highly adapted strategy to spread emergence over a longer period of time during winter when AAD cannot be accurately predicted. This model was developed as an alternative to a "leakage hypothesis" which assumed that most individuals emerging in winter did not survive to reproduce. Both alternatives, however, implicitly assumed a univoltine life cycle, which clearly does not occur in D. mendotae in Minnesota (Bouchard and Ferrington 2009). Results of this study, which show that $D$. cheimatophila may have three to four generations during winter, require that the "labile life cycle hypothesis" be modified slightly by proposing that bursts of emergence over relatively short temporal scales of three to four weeks can be considered adaptive for cohorts emerging during cooler portions of the year, but bursts of emergence over longer temporal scales (> five weeks) likely represent emergence of successive generations. In addition, the departure of emergence to times when AAD exceeds LTAD strongly suggests that individuals of a cohort have a mechanism to detect higher-than-average air temperatures, and can time their emergence to take advantage of less stressful air temperature conditions during the adult portion of the life cycle. This reinforces the assumption of the "labile life cycle hypothesis" as representing a highly adapted life cycle suited for emergence during winter.

\section{REFERENCES}

Adler PH, Travis BL, Kim KC, Masteller EC (1982) Seasonal Emergence Patterns of Black Flies (Diptera: Simuliidae) in Northwestern Pennsylvania. Great Lakes Entomol 15: 253-260.

Anderson AM, Ferrington LC Jr (2012) Resistance and resilience of winter-emerging Chironomidae (Diptera) to a flood event: implications for Minnesota trout streams. Hydrobiologia (electronic copy available through DOI 10.1007/s10750-012-1406-4).

Anderson AM, Kranzfelder P, Bouchard RW, Ferrington LC Jr (2013) Survivorship and longevity of Diamesa mendotae Muttkowski (Diptera: Chironomidae) under snow. J Entomol Acarol Res 45: 22-26.

Bouchard RW, Ferrington LC Jr (2009) Winter growth, development and emergence of Diamesa mendotae (Diptera: Chironomidae) in Minnesota Streams. Environ Entomol 38: 250-259.

Ferrington LC Jr (2000) Hibernal emergence patterns of Chironomidae in lotic habitats of Kansas versus ambient air and water temperatures. In: Hoffrichter O (ed) Late 20th Century Research on Chironomidae. Shaker Verlag, Aachen, Germany, pp. 375-382. 
Ferrington LC Jr, Karns B, Bouchard RW Jr (2010) Longevities of Diamesa mendotae Muttkowski, a hibernal emerging species of Chironomidae (Diptera). In: Ferrington LC Jr (ed) Proceedings of the XV International Symposium on Chironomidae. Chironomidae Research Group, University of Minnesota, Saint Paul, Minnesota, pp. 22-29.

Krider LA, Magner JA, Perry J, Vondracek B, Ferrington LC Jr (2013) Air-Water Temperature Relationships in the Trout Streams of Southeastern Minnesota's Carbonate-Sandstone Landscape. J Am Water Resour Assoc 49: 896-907. DOI: 10.1111/jawr.12046.

Lencioni V (2004) Survival strategies of freshwater insects in cold environments. J Limnol 63: 45-55.

Masteller EC (1977) An aquatic emergence trap on a shale stream of western Pennsylvania. Melsheimer Entomol Ser 23: 10-15.
Masteller EC, Buzby K (1993) Composition and temporal abundance of aquatic insect emergence from a tropical rainforest stream, Quebrada Prieta, at El Verde, Puerto Rico. Introduction. J Kansas Entomol Soc 66: 133-139.

Nolte U, Hoffmann T (1992) Fast life in cold water: Diamesa incallida (Chironomidae). Ecography 15: 25-30.

Rossaro B (1991) Chironomids and water temperature. Aquatic Insects 13: 87-98.

Rossaro B, Lencioni V, Mietto S (2000) Chironomids distribution in glacial streams and cold springs. In: Hoffrichter O (ed) Late 20th Century Research on Chironomidae. Shaker Verlag, Aachen, Germany, pp. 393-403.

Sæther OA (1969) Some nearctic Podonominae, Diamesinae and Orthocladiinae (Diptera: Chironomidae). B Fis Res Board Can 170: $1-154$. 